\title{
PELAYANAN PUBLIK MELALUI ELECTRONIC GOVERNMENT: UPAYA MEMINIMALISIR PRAKTEK MALADMINISTRASI DALAM MENINGKATAN PUBLIC SERVICE
}

\author{
Oleh : Erick S. Holle
}

\begin{abstract}
Direct contact in the provision of services provide great opportunities happening maladministration practice (failure to provide service). Therefore, it needs an effort to minimize or even eliminate the practice maladministration by utilizing information and communication technology (ICT) in the frame of electronic-government to service delivery, so that direct contact between service providers and service users no longer occur. In Indonesia, the opportunity for that already exist with the issuance of Presidential Instruction No. 3 of 2003 on National Policy and Strategy Development of electronic-Government (electronicGovernment framework), with the aim of supporting the change to democratic governance, facilitating communication between central and local governments, ensure the implementation of the principles of good governance, and facilitating the transformation towards an information society.
\end{abstract}

Kata Kunci: Electronic-Government, Public Services, Maladministration

\section{A. LATAR BELAKANG.}

Pemerintahan di seluruh dunia pada saat ini menghadapi "tekanan" dari berbagai pihak untuk meningkatkan kualitas pelayanan publik dan meningkatkan partisipasi aktif dalam pemberian informasi bagi masyarakat serta dituntut untuk lebih efektif. Hal tersebut menyebabkan $e$ Government atau pemerintahan berbasis elektronik semakin berperan penting bagi semua pengambil keputusan. Pemerintah Tradisional (traditional government) yang identik dengan paper-based administration mulai ditinggalkan. Transformasi traditional government menjadi electronic government (e-Government) menjadi salah satu isu kebijakan publik yang hangat dibicarakan saat ini. Di Indonesia e-Government baru dimulai dengan inisiatif yang dicanangkan beberapa tahun lalu.

Di dalam Undang-Undang Nomor 24 Tahun 2009 tentang Pelayanan Publik dalam bagian menimbang butir $\mathrm{b}$ dinyatakan :
Bahwa membangun kepercayaan masyarakat atas pelayanan publik yang dilakukan penyelenggara pelayanan publik merupakan kegiatan yang harus dilakukan seiring dengan harapan dan tuntutanseluruh warga negara dan penduduk tentang peningkatan pelayanan publik.

Dalam kaitan tersebut, reformasi birokrasi pemerintahan muncul pertama kali karena adanya keinginan pemerintah untuk memberikan pelayanan terbaik kepada masyarakat seperti yang ditentukan oleh UUD 1945. Peningkatan pelayanan publik (public service) harus mendapatkan perhatian utama dari pemerintah, karena pelayanan publik merupakan hak-hak sosial dasar dari masyarakat (social rihgts) ataupun fundamental rights). Landasan yuridis pelayanan publik atas hak-hak sosial dasar diatur dalam ketentuan Pasal 18 A ayat (2) dan Pasal 34 ayat (3) UUD 1945. Dengan demikian Undang-Undang Dasar mengatur secara tegas tentang pelayanan publik sebagai wujud hak sosial dasar (the rights to receive). Penolakan atau 
penyimpangan pelayanan publik adalah bertentangan dengan UUD $1945 .{ }^{1}$

Pelaksanaan public service sebagai hak-hak sosial dasar masyarakat di dalam realita masih banyak hambatan atau penyimpangan. Sering terjadi penyimpangan-penyimpangan dan bahkan kasus-kasus maladministrasi, dan KKN yang bisa berakibat yuridis pada pengenaan sanksi pidana.

Pada umumnya, proses pemberian pelayanan kepada publik (masyarakat) dewasa ini dilakukan melalui kontak langsung antara penyedia jasa layanan (birokrasi pemerintah) dengan warga masyarakat. Ternyata, kontak langsung seperti ini telah banyak dimanfaatkan oleh para pelaku interaksi pelayanan baik itu dari pihak birokrat (pemberi layanan) maupun dari pihak warga masyarakat (penerima layanan) Dari sisi pelayan, beberapa oknum pelayan sengaja mencari keuntungan dari pelayanan yang diberikannya misalnya dengan meminta sejumlah bayaran diluar ketentuan yang berlaku. Dari sisi warga masyarakat, beberapa oknum warga masyarakat yang ingin memperoleh layanan secara mudah dengan cara menyogok atau memberi uang "pelican" terhadap oknum aparat pelayan. Praktek-praktek semacam ini tentunya akan berdampak kepada pengguna jasa layanan lainnya, yang pada akhirnya akan berdampak pula pada kualitas pelayanan secara umum.

Beberapa hasil survei dari lembaga survei internasional menunjukkan bahwa pelayanan publik di Indonesia masih terburuk di Asia dalam hal pelayanan publik. Demikian pula halnya berbagai kajian yang telah dilakukan oleh para pemerhati pelayanan publik, dengan mana hampir semuanya berkesimpulan bahwa pelayanan publik melalui kontak langsung rentan terhadap berbagai praktek maladministrasi, yaitu suatu praktek yang menyimpang dari etika administrasi atau

\footnotetext{
${ }^{1}$ Philipus M. Hadjon, dkk, Hukum Administrasi dan Tindak Pidana Korupsi, Gadjah Mada University Press, Jogyakarta, 2011, hal. 26
}

suatu praktek administrasi yang menjauhkan dari pencapaian tujuan administrasi.

Praktek-praktek yang mengakibatkan terjadinya maladministrasi memang dimungkinkan dalam penyediaan layanan melalui kontak langsung. Pelayanan publik melalui kontak langsung akan sulit dihindari adanya perlakuan-perlakuan khusus yang berdampak pada penyimpangan terhadap ketentuan administrasi. Sebagaimana dicontohkan, ketika seorang warga masyarakat yang datang kebetulan adalah keluarga dekat atau orang yang memiliki kedudukan yang penting di daerah itu, maka secara otomatis pelayan publik akan memberikan perlakuan khusus terhadap warga semacam ini, apakah dengan memberikan prioritas untuk dilayani, atau bahkan sampai kepada pengabaian persyaratan yang semestinya harus dipenuhi. Tindakan-tindakan seperti ini tentunya akan berdampak kepada terciptanya pelayanan yang dikriminatif yang dapat memicu rasa ketidakadilan masyarakat.

\section{B. PEMBAHASAN}

\section{Definisi Pelayanan Publik.}

Dalam Undang-Undang Nomor 25 tahun 2009 tentang Pelayanan Publik, ditegaskan dalam Pasal 1 butir 1 :

"Pelayanan publik adalah kegiatan atau rangkaiang kegiatan dalam rangka pemenuhan kebutuhan pelayanan sesuai dengan peraturan perundang-undangan bagi setiap warga negara dan penduduk atas barang, jasa dan/atau pelayanan administratif yang dielenggarakan oleh penyelenggara pelayanan publik".

Keputusan Menteri Pendayagunaan Aparatur Negara Nomor. 63 Tahun 2003 mendefenisikan pelayanan publik sebagai:

"Segala bentuk pelayanan yang dilaksanakan oleh Instansi Pemerintah di Pusat, di Daerah dan di lingkungan Badan Usaha Milik Negara atau Badan Usaha Miliki Daerah dalam bentuk 
barang dan atau jasa, baik dalam rangka upaya pemenuhan kebutuhan masyarakat maupun dalam rangka pelaksanaan ketentuan peraturan perundangundangan".

Mengikuti defenisi tersebut di atas, pelayanan publik atau pelayanan umum dapatdidefinisikan sebagai segala bentuk kegiatan pelayanan umum yang dilaksanakan oleh instansi pemerintah di pusat, di daerah, dan lingkungan Badan Usaha Milik Negara (BUMN) maupun Badan Usaha Milik Daerah (BUMD) dalam bentuk barang dan jasa baik dalam rangka upaya pemenuhan kebutuhan masyarakat maupun dalam rangka pelaksanaan ketentuan perundang -undangan.

Hakekat Pelayanan Publik antara lain :

a. Meningkatkan mutu dan produktivitas pelaksanaan tugas dan fungsi pemerintah di bidang pelayanan publik.

b. Mendorong upaya mengefektifkan sistem dan tata laksana pelayanan, sehingga pelayanan publik dapat diselenggarakan lebih berdaya guna dan berhasil guna.

c. Mendorong tumbuhnya kreativitas, prakasa, dan peran serta masyarakat dalam derap langkah pembangunan serta dalam upaya meningkatkan kesejahteraan masyarakat luas.

Pada dasarnya pembangunan nasional suatu bangsa dilaksanakan oleh masyarakat bersama pemerintah, masyarakat adalah pelaku utama pembangunan, sedangkan pemerintah berkewajiban untuk mengarahkan, membina serta menciptakan suasana kondusif yang menunjang kegiatan rakyatnya. Kegiatan masyarakat dan pemerintah tersebut harus saling mengisi, saling menunjang, dan saling melengkapi dalam suatu kesatuan langkah menuju tercapainya suatu tujuan pembangunan nasional suatu bangsa.

Pemberian pelayanan umum oleh aparatur pemerintah kepada masyarakat adalah merupakan perwujudan dari fungsi aparat negara, agar terciptanya suatu keseragaman pola dan langkah pelayanan umum oleh aparatur pemerintah perlu adanya suatu landasan yang bersifat umum dalam bentuk pedoman tata laksana pelayanan umum. Pedoman ini merupakan penjabaran dari hal-hal yang perlu mendapatkan perhatian dalam prosedur operasionalisasi pelayanan umum yang diberikan oleh instansi pemerintah baik di pusat maupun di daerah secara terbuka dan transparan.

\section{Praktek Maladministrasi Dalam Pelayanan Publik}

Pengertian maladministrasi sebagaimana dalam kamus Cambridge mendefinisikan maladministrasi sebagai lack of care, judgment or honesty in the management of something, atau dapat diartikan sebagai kekurangpedulian atau ketidakjujuran seseorang dalam mengelola sesuatu. Sedangkan dalam Wikipedia mendefenisikan maladministrasi sebagai sesuatu yang memiliki makna yang luas dan mencakup antara lain: ${ }^{2}$

a. Delay (menunda-nunda pekerjaan)

b. Incorrect action or failure to take any action (kesalahan dalam bertindak atau melayani)

c. Failure to follow procedures or the law (mengabaikan prosedur atau hukum yang berlaku)

d. Failure to provide information (kesalahan dalam memberi kan informasi)

e. Inadequate record-keeping (pencatatan yang tidak memadai)

f. Failure to investigate (kesalahan dalam penyelidikan)

g. Failure to reply (kesalahan dalam menjawab)

h. Misleading or inaccurate statements (pernyataan yang menyesatkan atau tidak akurat)

i. Inadequate liaison ( kurangnya penghubung)

\footnotetext{
${ }^{2}$ www.wikipedia.com
} 


\section{j. Inadequate consultation (kurangnya konsultasi) \\ k. Broken promises (ingkar janji)}

Sementara itu Hartono, dkk (2003) dalam Buku Panduan Investigasi untuk Ombudsman Indonesia memberikan pengertian maladminsitrasi secara umum adalah perilaku yang tidak wajar (termasuk penundaan pemberian pelayanan), tidak sopan dan kurang peduli terhadap masalah yang menimpa seseorang disebabkan oleh perbuatan penyalahgunaan kekuasaan termasuk penggunaan kekuasaan secara semena-mena atau kekuasaan yang digunakan untuk perbuatan yang tidak wajar, tidak adil, intimidatif atau diskriminatif, dan tidak patut didasarkan seluruhnya atau sebagian atas ketentuan undang-undang atau fakta, tidak masuk akal, atau tidak berdasarkan tindakan unreasonable, unjust, oppressive, improper, dan diskriminatif. ${ }^{3}$

Lebih lanjut Hartono, dkk menyebutkan bahwa maladministrasi dapat merupakan perbuatan, sikap maupun prosedur dan tidak terbatas pada hal-hal administrasi atau tata usaha saja. Hal-hal maladministrasi tersebut menjadi salah satu penyebab bagi timbulnya pemerintahan yang tidak efisien, buruk dan tidak memadai. Dengan kata lain, bahwa tindakan atau perilaku maladministrasi bukan sekedar merupakan penyimpangan dari prosedur atau tata cara pelaksanaan tugas pejabat atau aparat negara atau aparat penegak huku, akan tetapi juga dapat

merupakan perbuatan melawan hukum.

Masthuri dalam bukunya yang berjudul "Mengenal Ombudsman Indonesia" mengklasifikasikan bentuk dan jenis maladministrasi menjadi enam kelompok berdasarkan kedekatan karakteristik sebagai berikut : ${ }^{4}$

\footnotetext{
${ }^{3}$ Hartono, Sunaryati; Budhi Masthuri, Enni Rochmaeni, Winrso. Panduan Investigas untuk Ombudsman Indonesia, The Asia Foundation Indonesia, 2003

${ }^{4}$ Masthuri, Budi, Mengenal OmbudsmanIndonesia. Pradnya Paramita, Jakarta, 2005
}

a. Bentuk-bentuk maladministrasi yang terkait dengan ketepatan waktu dalam proses pemberian pelayanan umum, dapat berupa tindakan-tindakan seperti berikut ini:

\section{Penundaan Berlarut}

Dalam proses pemberian pelayanan publik kepada masyarakat, seorang pejabat publik secara berkalikali menunda atau mengulur-ulur waktu tanpa alasan yang jelas sehingga proses administrasi yang sedang dikerjakan menjadi tidak tepat waktu sebagaimana ditentukan (secara patut). Tindakan seperti ini dapat mengakibatkan pelayanan publik yang diberikan memiliki tingkat ketidakpastian yang tinggi.

2. Tidak Menangani

Seorang pejabat publik sama sekali tidak melakukan tindakan yang semestinya wajib dilakukan dalam rangka memberikan pelayanan publik kepada masyarakat.

3. Melalaikan Kewajiban

Dalam proses pemberian pelayanan publik, seorang pejabat publik bertindak kurang hati-hati dan tidak mengindahkan apa yang semestinya menjadi tanggung jawabnya.

b. Bentuk-bentuk maladministrasi yang mencerminkan keberpihakan sehingga menimbulkan rasa ketidakadilan dan diskriminasi. Kelompok ini terdiri dari tindakan-tindakan:

1. Persekongkolan

Beberapa pejabat publik yang bersekutu dan turut serta melakukan kejahatan, kecurangan, melawan hukum sehingga masyarakat merasa tidak memperoleh pelayanan secara baik dan berkeadilan. Tindakan seperti ini dapat menurunkan kepercayaan masyarakat terhadap pelayan publik.

2. Kolusi dan Nepotisme

Dalam proses pemberian pelayanan kepada masyarakat, seorang pejabat publik melakukan tindakan ter tentu 
untuk mengutama kan keluarga/sanak famili, teman dan kolega sendiri tanpa kriteria objektif dan tidak dapat dipertanggungjawabkan (tidak akuntabel), baik dalam hal pemberian pelayanan maupun untuk dapat duduk dijabatan atau posisi dalam lingkungan pemerintahan.

3. Bertindak Tidak Adil

Dalam proses pemberian pelayanan, seorang pejabat publik melakukan tindakan memihak, melebihi atau mengurangi dari yang sewajarnya sehingga masyarakat memperoleh pelayanan umum tidak sebagaimana mestinya.

4. Nyata-nyata Berpihak

Dalam proses pemberian pelayanan umum, seorang pejabat publik bertindak berat sebelah dan lebih mementingkan salah satu pihak tanpa memperhatikan ketentuan yang berlaku sehingga keputusan yang diambil merugikan pihak lainnya.

\section{c. Bentuk-bentuk maladministrasi yang} lebih mencerminkan sebagai bentuk pelanggaran terhadap hukum dan peraturan perundangan. Kelompok ini terdiri dari tindakan-tindakan sebagai berikut:

1. Pemalsuan

Perbuatan meniru sesuatu secara tidak sah atau melawan hukum untuk kepentingan menguntungkan diri sendiri, orang lain dan/atau kelompok sehingga menyebabkan masyarakat tidak memperoleh pelayanan secara baik.

2. Pelanggaran Undang-Undang.

Dalam proses pemberian pelayanan, seorang pejabat publik secara sengaja melakukan tindakan menyalahi atau tidak mematuhi ketentuan perundangan yang berlaku sehingga masyarakat tidak memperoleh pelayanan secara baik.

3. Perbuatan Melawan Hukum
Dalam proses pemberian pelayanan, seorang pejabat publik melakukan perbuatan bertentangan dengan ketentuan ber laku dan kepatutan sehing ga merugikan masyarakat yang semsetinya memperoleh pelayanan publik.

d. Bentuk-bentuk maladministrasi yang terkait dengan kewenangan kompetensi atau ketentuan yang berdampak pada kualitas pelayanan yang diberikan pejabat publik kepada masyarakat. Kelompok ini terdiri dari tindakan-tindakan sebagai berikut:

1. Diluar Kompetensi

Dalam proses pemberian pelayanan publik, seorang pejabat publik memutuskan sesuatu yang bukan menjadi kewenangannya sehingga masyarakat tidak memperoleh pelayanan secara baik.

2. Tidak Kompeten

Dalam proses pemberian pelayanan, seorang pejabat publik tidak mampu atau tidak cakap dalam memutuskan sesuatu sehingga pelayanan yang diberikan kepada masyarakat menjadi tidak memadai (tidak cukup baik).

3. Intervensi

Seorang pejabat publik melakukan campur tangan terhadap kegiatan yang bukan menjadi tugas dan kewenangannya mempengaruhi proses pemberian pelayanan kepada masyarakat.

4. Penyimpangan Prosedur

Dalam proses pemberian pelayanan publik, seorang pejabat publik tidak mematuhi tahapan kegiatan yang telah ditentukan dan secara patut sehingga masyarakat tidak memperoleh pelayanan secara baik.

e. Bentuk-bentuk maladministrasi yang mencerminkan sikap arogansi seorang pejabat publik dalam proses pemberian pelayanan publik kepada masyarakat. 
Kelompok ini terdiri dari beberapa tindakan sebagai berikut:

1. Bertindak Sewenang-wenang

Seorang pejabat publik menggunakan wewenangnya (hak dan kekuasaan untuk bertindak) melebihi apa yang sepatutnya dilakukan sehingga tindakan dimaksud bertentangan dengan ketentuan yang berlaku, menjadikan pelayanan publik tidak dapat diterima secara baik oleh masyarakat.

2. Penyalahgunaan Wewenang

Seorang pejabat publik menggunakan wewenangnya (hak dan kekuasaan untuk bertindak) untuk keperluan yang tidak sepatutnya sehingga menjadikan pelayanan publik yang diberikan tidak sebagaimana mestinya.

3. Bertindak Tidak Layak/ Tidak Patut Dalam proses pemberian pelayanan publik, seorang pejabat publik melakukan sesuatu yang tidak wajar, tidak patut, dan tidak pantas sehingga masyarakat tidak mendapatkan pelayanan sebagaimana mestinya.

\section{f. Bentuk-bentuk maladministrasi yang} mencerminkan sebagai bentuk-bentuk korupsi secara aktif. Kelompok ini terdiri dari tindakan-tindakan sebagai berikut:

1. Permintaan Imbalan Uang/Korupsi,

Dalam proses pemberian pelayanan publik kepada masyarakat, seorang pejabat publik meminta imbalan uang dan sebagainya atas pekerjaan yang sudah semestinya dia lakukan (secara cuma-cuma) karena merupakan tanggung jawabnya, dan telah digaji oleh pemerintah dari uang rakyat yang dibayarkan melalui pajak mereka. Seorang pejabat publik menggelapkan uang negara, perusahaan (negara), dan sebagainya untuk kepentingan pribadi atau orang lain sehingga menyebabkan pelayanan umum tidak dapat diberikan kepada masyarakat secara baik.
2. Penguasaan Tanpa Hak

Seorang pejabat publik menguasai sesuatu yang bukan milik atau kepunyaannya secara melawan hak, padahal semestinya sesuatu tersebut menjadi bagian dari kewajiban pelayanan publik yang harus diberikan kepada masyarakat.

3. Penggelapan Barang Bukti

Seorang pejabat publik terkait dengan proses penegakan hukum telah menggunakan barang, uang dan sebagainya secara tidak sah, yang merupakan alat bukti suatu perkara. Akibatnya, ketika fihak yang berperkara meminta barang bukti tersebut (misalkan setelah tuduhan tidak terbukti) pejabat publik terkait tidak dapat memenuhi kewajibannya.

Demikian beberapa praktek-praktek maladministrasi yang dapat terjadi dari kegiatan pelayanan publik yang diberikan para pejabat publik kepada warga masyarakat. Praktek maladministrasi sebagaimana disebutkan di atas kecenderungannya besar terjadi pada pelayanan publik yang disediakan dengan cara kontak langsung antara penyedia layanan dengan pengguna jasa layanan terutama yang berkaitan dengan sikap arogansi pelayan publik.

\section{Konsep Dasar Electronic Government (e-Gov)}

Perkembangan teknologi informasi dan komunikasi (Information and communication Technology, ICT) telah membawa pengaruh yang besar terutama bagi organisasi pemerintahan. Perkembangan teknologi informasi ini telah memaksa organisasi pemerintah untuk melakukan transformasi besar-besaran agar selalu memberikan pelayanan terbaik kepada masyarakat. Perubahan tersebut tidak hanya 
dalam produk layanan, tetapi juga pada struktur dan manajemen organisasi.

Di Negara-negara maju, e-gov merupakan hasil transformasi mekanisme interaksi birokrasi dengan masyarakat yang menjadi lebih bersahabat. Demikian halnya di Negara berkembang, banyak pengambil kebijakan yakin bahwa pemerintahan yang bersih, berwibawa, dan transparan dapat diwujudkan melalui e-government. ${ }^{6}$

Secara konseptual, konsep dasar dari e-Government sebenarnya adalah bagaimana memberikan pelayanan melalui elektronik (e-service), seperti melalui internet, jaringan telepon seluler dan komputer, serta multimedia. Melalui pengembangan $e$-Gov ini, maka sejalan dengan itu dilakukan pula penataan system manajemen informasi dan proses pelayanan publik dan mengoptimalkan pemanfaatan teknologi informasi dan komunikasi. ${ }^{7}$

Adapun ruang lingkup dari $e-G o v$ ini adalah mencakup interaksi antara pemerintah dan masyarakat (G2Cgovernment to citizens), pemerintah dan perusahaan bisnis (G2B-government to business enterprises) dan hubungan antar pemerintah

(G2G-inter-agency relationship). Sementara itu, Forman memberikan defenisi e-government secara lebih spesifik lagi yakni penggunaan teknologi digital untuk mentransformasi kegiatan-kegiatan pemerintah yang bertujuan untuk meningkatkan efektivitas dan efisiensi penyampaian layanan. Dari defenisi yang dikemukakan oleh Forman tadi bermakna bahwa penyampaian layanan melalui teknologi digital dapat memberikan tingkat efisiensi dan efektivitas pekerjaan pemerintah yang lebih baik. Efisiensi dalam

\footnotetext{
${ }^{5}$ W. Bennis. and M.Mische,. The 21 Century Organization. Pfeiffer\&Company.NewYork, 1995

${ }^{6}$ R.E. Indrajit. E-Government: Strategi Pembangunan dan Pengembangan Sistem Pelayanan Publik Berbasis Teknologi Digital, Jogyakarta, 2002

${ }^{7}$ Alexander Rusli (ed), Telematika Indonesia: Kebijakan dan Perkembangan. Tim Koordinasi Telematika Indonesia Kementerian Komunikasi dan Informasi Republik Indonesia, Jakarta,2004
}

hal ini baik dari segi waktu, biaya, maupun tenaga. ${ }^{8}$

Menurut Okut-Uma dan Caffrey sebagaimana yang dikutip oleh Suprawoto, e-Government didefenisikan sebagai the processes and structures pertinent to the electronic delivery of government services to the public. ${ }^{9}$

Bank Dunia menyebut EGovernment mengarahkan untuk penggunakan Teknologi Internet oleh semua agen pemerintahaan (seperti WAN, internet, mobile computing) yang mempunyai kemampuan untuk mengubah hubungan dengan masyarakat, bisnis, dan pihak yang terkait dengan pemerintahan. Sementara, Yong menyebut e-Government adalah upaya penggunaan teknologi dalam mengubah organisasi publik untuk melakukan penataan ulang dan perbaikan struktur, proses administrasi dan jaringan serta jangkauan layanan publik.

Dari beberapa definisi yang dikemukakan di atas, setidaknya terdapat tiga karakteristik utama dari e-Government, yaitu: (1) merupakan suatu mekanisme interaksi baru antara pemerintah dan masyarakat dan kalangan lain yang berkepent ingan (stakeholders); melibatkan penggunaan teknologi informasi (terutama internet dan jaringan seluler); (3) memperbaiki mutu (kualitas) pelayanan publik. Meskipun demikian dalam kenyataannya tidak ada standar baku dalam pengembangan $e$-Government.

\section{Meminimalisir}

Praktek Maladministrasi Melalui Pemberian Pelayanan Publik Melalui $E$ Government (E-Services).

Maladministrasi dalam berbagai bentuk dan jenis sebagaimana yang telah diuraikan dalam pembahasan sebelumnya

\footnotetext{
${ }^{8}$ Mark Forman,. E-Government: Using IT to Transform the Effectiveness and Efficiency of Government.,2005

9 Suprawoto, Pelayanan Publik Melalui E-Government (Studi tentang Pelayanan KTP, e-Procurement dan PSBOnline di Kota Surabaya). Universitas Brawijaya, Malang, 2007
} 
dapat diminimalisir atau bahkan dapat dihilangkan apabila pelayanan publik tidak lagi diberikan secara tatap muka atau kontak langsung, melainkan diberikan melalui elektronik yang dikenal dengan istilah eservices. Meskipun memang diakui bahwa tidak semua jenis pelayanan publik dapat disediakan sepenuhnya melalui elektronik dalam bingkai $e-G o v$. Akan tetapi beberapa dari kegiatan pelayanan publik ini dapat disediakan melalui elektronik, misalnya saja jenis pelayanan administratif seperti pelayanan kependudukan (KTP, akta kelahiran, surat nikah), pelayanan perizinan, dan lain-lain. Demikian pula halnya dalam hal pelayanan pengadaan barang dan jasa di lingkungan instansi pemerintah. Dalam beberapa tahun terakhir dikembangkan electronic procurement (e-procurement) oleh pemerintah.

Dengan e-procurement ini maka, maladministrasi seperti persekongkolan antara pengusaha (pelaku tender) dengan oknum panitia tender tidak lagi bisa terjadi. Secara rinci dapat dicontohkan beberapa jenis pelayanan publik yang memungkinkan untuk disediakan melalui e-govantara lain adalah: pengurusan KTP, pelayanan perizinan, pembayaran pajak, pelaporan pindah alamat, pelaporan kelahiran, pendaftaran pernikahan, motor vehicle registration, Informasi pelayanan kesehatan, perpanjangan Surat Izin Mengemudi (SIM), mencari dan melamar kerja.

E-Services yaitu suatu metode pemberian pelayanan dengan memanfaatkan teknologi informasi dan komunikasi dengan mana aparat pelayan publik tidak lagi bertemu langsung (seemless) dengan warga masyarakat pengguna jasa layanan. Dengan demikian, maka praktek-praktek maladministrasi sebagaimana yang disebutkan di atas tidak lagi mudah terjadi. Pelayanan tidak lagi melihat langsung siapa orang yang dilayani karena hanya terhubung dengan teknologi. Demikian pula halnya yang dilayani, ia tidak lagi melihat siapa yang melayaninya, sehingga peluang terjadinya kolusi dan nepotisme dalam pelayanan publik akan terhindarkan.

Disamping bertujuan untuk menghindarkan praktek-praktek maladministrasi dalam pelayanan publik, eservices memiliki beberapa manfaat langsung lainnya antara lain sebagai berikut:

a) Meningkatkan efisiensi dan efektivitas kerja dari pemerintah.

b) Mempercepat proses pemberian layanan kepada masyarakat

c) Informasi yang diberikan akan lebih lengkap, cepat dan akurat dengan biaya yang lebih efisien dalam pengeloloaan data dan pencarian informasi.

d) Secara umum dapat mendukung terciptanya good governance

e) Dapat meningkatkan daya tarik bagi investor dan dunia usaha untuk masuk ke wilayah pemerintah.

f) Mempercepat proses penyampaian pelaporan ketika dibutuhkan oleh para pengambil kebijakan.

g) Meningkatkan interaksi dengan dunia usaha

h) Memberdayakan masyarakat melalui distribusi informasi dan transparansi serta dalam pengambilan keputusan.

i) Tersedianya database kabupaten/kota yang up to date

Dari uraian di atas, secara ringkas tujuan yang ingin dicapai dengan implementasi $e$-Gov adalah untuk menciptakan customer online dan bukan inline. E-Gov bertujuan memberikan pelayanan tanpa adanya intervensi pegawai institusi publik dan sistem antrian yang panjang hanya untuk mendapatkan suatu pelayanan yang sederhana. Selain itu $e$-Gov juga bertujuan untuk mendukung good governance. Penggunaan teknologi yang mempermudah masyarakat untuk mengakses informasi dapat mengurangi korupsi dengan cara meningkatkan transparansi dan akuntabilitas lembaga publik.

E-Gov dapat memperluas partisipasi publik dimana masyarakat dimungkinkan untuk terlibat aktif dalam pengambilan keputusan/kebijakan oleh pemerintah. E-gov 
juga diharapkan dapat memperbaiki produktifitas dan efisiensi birokrasi serta meningkatkan pertumbuhan ekonomi. Praktek-praktek maladministrasi seyogyanya telah dapat diminimalisir dengan berupaya untuk memberikan pelayanan melalui e-gov (e-services). Namun dalam kenyataannya, khususnya di Indonesia, dari beberapa penelitian yang dilakukan terhadap pengembangan $e$-gov untuk tujuan pelayanan publik, baru beberapa pemerintah daerah yang telah mampu mengembangkan e-gov mereka untuk tujuan pemberian pelayanan kepada masyarakat. Sebut saja misalnya Kabupaten Sragen yang telah menjangkau 298 desa dan 20 kecamatan . Egov yang telah dikembangkan di Kabupaten Sragen sejak tahun 2002 ini sangat membantu memperlancar pelayanan di lingkungan pemerintahan Kabupaten Sragen, misalnya saja untuk mengurus KTP pemohon tidak perlu menunggu lama. Karena keberhasilan ini, maka Sragen menjadi pusat studi banding e-gov, dan bahkan telah mendampingi lebih dari 25 kabupaten/kota dalam pengembangan e-gov. Keberhasilan Kabupaten Sragen dalam mengembangkan e-gov rupanya bukan hal yang mudah untuk dilakukan.

Berbagai upaya yang harus dilakukan oleh pemerintah kabupaten/kota apabila ingin seperti apa yang telah dicapai oleh Sragen antara lain adalah perlunya komitmen yang kuat dari pemerintah daerah untuk mengembangkan e-gov. Komitmen ini dapat dilihat dari pengalokasian dana yang tidak sedikit, terutama untuk penyediaan dan pemeliharan jaringan internet/website, penyediaan sumberdaya manusia yang handal untuk mendukung kesuksesan pelaksanaan $e$-gov.

\section{P E N U T U P}

Kontak langsung dalam pemberian pelayanan memberi peluang yang besar terjadinya praktek maladministrasi. Oleh karenanya, maka diperlukan sebuah upaya untuk meminimalisir atau bahkan menghilangkan praktek maladministrasi dengan memanfaatkan teknologi informasi dan komunikasi dalam bingkai electronic government dalam pemberian pelayanan, sehingga kontak langsung antara penyedia layanan dan pengguna layanan tidak lagi terjadi. Di Indonesia, peluang untuk itu sudah ada dengan dikeluarkannya Inpres Nomor 3 Tahun 2003 tentang Kebijakan dan Strategi Nasional Pengembangan e-Gov (electronic-Government framework), salah satu tujuannya adalah memberikan pelayanan publik yang berkualitas yang memenuhi prinsip-prinsip tata kelola pemerintahan yang baik (good governance).

\section{DAFTAR PUSTAKA}

Bennis,W. and M.Mische, 1995. The 21 Century Organization. Pfeiffer\&Company.New York.

Forman, Mark, 2005. E-Government: Using IT to Transform the Effectiveness and Efficiency of Government.

Hartono, Sunaryati; Budhi Masthuri, Enni Rochmaeni, Winarso, Panduan Investigasi untuk Ombudsman Indonesia, Diterbitkan atas dukungan The Asia Foundation Indonesia.2003

Hadjon M. Philipus, dkk, Hukum Administrasi dan Tindak Pidana Korupsi, Gadjah Mada University Press, Jogyakarta, 2011

Indrajit, R.E. E-Government: Strategi Pembangunan dan Pengembangan Sistem Pelayanan Publik Berbasis Teknologi Digital. Penerbit: Andi, Yogyakarta.2002

Masthuri, Budi, Mengenal Ombudsman Indonesia. Penerbit: Pradnya Paramita, Jakarta, 2005 
Erick S. Holle, Pelayanan Publik Melalui E-Gov..................... 30 Jurnal Sasi Vol.17 No.3 Bulan Juli-September 2011

Rusli, Alexander (ed), Telematika

Indonesia: Kebijakan dan

Perkembangan. Tim Koordinasi

Telematika Indonesia

Kementerian Komunikasi dan

Informasi Republik Indonesia, Jakarta, 2004

Suprawoto, Pelayanan Publik Melalui EGovernment (Studi tentang Pelayanan KTP, e-Procurement dan PSB-Online di Kota Surabaya). Disertasi. Universitas Brawijaya, Malang.2005

\section{Aturan Hukum :}

Undang-Undang Dasar 1945

Undang-Undang Nomor 24 Tahun 2009 tentang Pelayanan Publik

Keputusan Menteri Pendayagunaan

Aparatur Negara Nomor 63 Tahun 2003 tentang

Pedoman Umum Penyelenggaraan Pelayanan Publik

Inpres Nomor 3 Tahun 2003 tentang Kebijakan dan Strategi Nasional Pengembangan e-Gov (electronicGovernment framework) 